\title{
Traian Vuia's contribution to the development of propulsive power
}

\author{
Ioana Ionel \\ Politehnica University Timisoara, Faculty for Mechanical Engineering, Bv. M. Viteazu 1, 300222, \\ Timisoara, \\ ioana.ionel@upt.ro
}

\begin{abstract}
The paper describes, based on recherché of documents, the invention of Traian Vuia consisting of the steam generator, meant to offer in very short time, a sufficient propulsive power. The construction was considered and still is a remarkable contribution to the steam boilers development, basically applying enhanced combustion, heat transfer principles, as well as forced circulation.
\end{abstract}

Keywords: steam generator, efficiency, enhanced combustion, heat transfer

\section{Introduction: The boiler was a necessity}

Among other inventions, Vuia designed also a steam generator, patented in many countries of the world in the interwar period. Even since 1902, when he arrived in France, Traian Vuia was preoccupied with building a suitable motor for driving his heavier than air flying machine and capable of taking off using its own propulsive power.

The engine with carbon dioxide, designed and built by Vuia for driving the airplane with which on March 18, 1906, on the field of Montesson, he achieved the epochal flight, did not satisfy him because it was not strong enough, was not very reliable while functioning, had poor efficiency and the working fluid used was consumable. Not even the internal combustion engines, with either spark ignition or compression, met Vuia's requirements since, being at the beginning of their development, they realized low unitary power, had poor efficiency and a large weight compared to the power output. Due to this, Vuia considered the best thermodynamic agent was high pressure and temperature steam, aimed to relax in a turbine, which would drive the propeller of the plane. The exhaust steam was to be condensed and the condensation was to be returned to the steam generator.

This original idea of using a closed thermodynamic cycle involved the realization of an energy engine group composed mainly of a steam boiler, a turbine, a condenser, pumps, blowers, etc. All this together were to weigh so little and have small dimensions in order to enable installation on a plane, which was supposed to lift off by itself and fly safely. It was hard to believe that this could be done at that time and therefore this idea was regarded with restraint and countered by quite many.

\section{Concept}

How was it possible to rapidly make a steam generator, which to be put into operation in 1-3 minutes, to produce steam at $p=100-120$ bar and $t_{s}=400-5000 \mathrm{C}$, to have an hourly flow rate of about 10 times its own weight, considering that at that time, the vast majority of boilers operated at a pressure of $p=10$ bar, producing saturated or slightly overheated steam, contained a very large volume of water and were put into operation in 2 - 4 hours? But, still, it was possible!

At the core concept of this steam generator, Vuia sensed the need to introduce three fundamental ideas that had just revolutionized the technique of constructing steam generators: (i) enhanced combustion, (ii) increase heat transfer and (iii) forced circulation boiler.

Obviously, each of these ideas would require an extensive description, but, the following section aims to point out some characteristic features in order to make clear the leap in the technical thinking back then, realized by introducing Traian Vuia's innovative ideas in the construction of steam generators.

Accelerated combustion is characterized by a high combustion speed. To achieve this goal, Traian Vuia equipped his steam generator with a burner of a special construction very similar to a carburetor (Figure 1).

When it starts, the fuel mixture is ignited by a spark plug. Combustion is going on inside a refractory steel furnace tube, highly alloyed with $\mathrm{Cr}$ and $\mathrm{Ni}$, which during operation is heated to incandescence. In these circumstances, the rate of the chemical reaction of oxidation of the combustible elements is determined only by the constant of the reaction rate $\mathrm{K}$, whose temperature dependence is expressed by Arrhenius law:

$$
K=K_{0} \cdot e^{\frac{E}{R T}}
$$

(1)

where: $\mathrm{K}_{0}$ is the pre-exponential factor, considered by the kinetic theory as a size proportional to the total number of collisions between the molecules of the 
substances that take part in the reaction;

E - Activation energy in $\mathrm{W} / \mathrm{mol}$;

$\mathrm{R}$ - Universal constant for gas, in $\mathrm{W} /(\mathrm{mol} / \mathrm{K})$;

$\mathrm{T}$ - Absolute temperature, in $\mathrm{K}$.

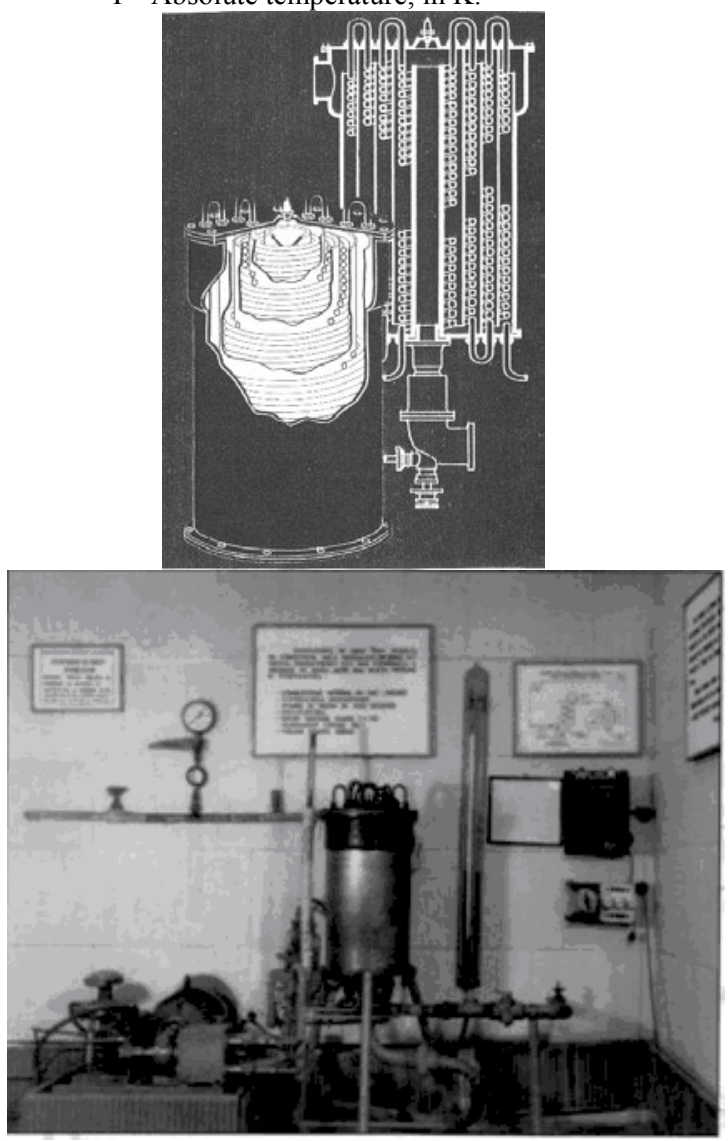

Figure 1. View and section through Vuia's steam generator, [1], [4].

Equation (1) shows that the reaction rate increases along with the temperature of the reaction system. If for small values of $\mathrm{T}$, the growth of the reaction rate is modest, after exceeding a certain threshold temperature, the reaction rate increases very rapidly after an exponential law. This is precisely the situation in which combustion occurs in the furnace tube of Vuia's boiler, where the average temperature stabilizes around $\mathrm{T}_{\mathrm{m}}=$ $1800-2000 \mathrm{~K}$, and the thermal load reaches about $\mathrm{q}_{\mathrm{f}}=$ $460 \mathrm{~kW} / \mathrm{m}^{3}$.

The intensification of the heat transfer from the flue gases to the water and steam flowing in the pipes was sensed and carried out by Vuia using forced convection at high speed and counter current circulation of working fluids. Indeed, the mathematical expression of the coefficient of heat transfer $\left(\mathrm{k}_{1}\right)$ written for a tubular heating area (Figure 2 )indicates that in order to increase the value of $k_{1}$, the value of the coefficient of thermal convection $\alpha_{1}$ from the flue gases to the pipe walls must be increased. This is because the heat resistance, conductive through the wall $\left(\frac{d_{1}}{2 \lambda} \ln \frac{d_{1}}{d_{2}}\right)$ and convective from the wall to the fluid flowing through the pipes $\left(\frac{1}{\alpha_{2}}\right)$ is lower than the thermal resistance of the flue gases at the wall $\left(\frac{1}{\alpha_{1}} \frac{d_{1}}{d_{2}}\right)$

$$
k_{1}=\frac{1}{\frac{1}{\alpha_{1}} \frac{d_{1}}{d_{2}}+\frac{d_{1}}{2 \lambda} \ln \frac{d_{1}}{d_{2}}+\frac{1}{\alpha_{2}}}\left[\frac{W}{m^{2} K}\right]
$$

For a given report of the pipe diameter, the increase of $\alpha_{1}$ leads directly to increasingits value.

It is known that, in the case of forced convection,invariant Nusseltis dependent on invariant Reynolds and Prandtl:

$$
N_{s}=f\left(R_{r}^{n} P_{r}^{m}\right)
$$

(3)

or explained:

$$
\frac{\alpha d}{\lambda}=C\left(\frac{w d}{v}\right)^{0,8}\left(\frac{v}{a}\right)^{0,4}
$$

(4)

Whereas the average values of cinematic viscosity $v$, thermal diffusivity a, and thermal conductivity $\lambda$ remain practically constant, equation (4) indicates that the value of the convection coefficient increases along with gas velocity $\mathrm{w}$ at power 0.8 . If in the case of conventional boilers the flue gases circulation rate varies within limits 6- $14 \mathrm{~m} / \mathrm{s}$, in the case of Vuia's boiler, this size has a value of $120-150 \mathrm{~m} / \mathrm{s}$. This leads to a growth of the convection coefficient value of about 8-10 times, compared to the values found for conventional boilers.

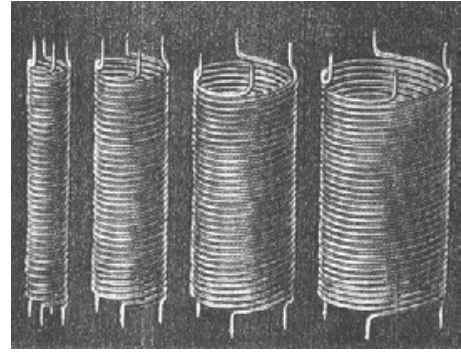

Figure 2. Concentric heating surface made of spirally wound pipes [1], [4].

Among the possible variants of boilers with natural circulation of the water in the vaporizer, with multiple forced circulation and with forced circulation, Vuia chose 
the latter one for his boiler. Forced circulation boilers have the heating surface formed by one or more very long serpentine pipe with a small diameter of $10-20 \mathrm{~mm}$. At one end of the coil, it enters feed water, and, at the other end, it comes out superheated steam. The processes of steam heating, vaporization and superheating occur one after another, along the coil; the border between the economizer, vaporizer and super heater is sliding, depending on how it is achieved the equality between the heat flow received from the flue gases and the heat flow necessary for the transformation offered water into superheated steam.

Traian Vuia designed and realized five steam generators, having 2 to 32 coils, made of pipe with $d=10$ $\mathrm{mm}$, spirally wound in four concentric cylinders. In Table 1 , the main dimensions of Vuia's steam generators are presented, and in Figure 3 a section is indicated, which shows the arrangement of the surfaces, as well as the direction of counter current circulation of the flue gases, water and steam, respectively.

The heating surface is composed of coils connected in series and coaxial with a central furnace tube. The metal body of the boiler, which is made of heat-resistant tin, has a cylindrical shape and is closed with two lids at the ends. The gas channels have annular section and are shaped by cylindrical tin obstacles (coaxial with the central tube). They are fixed in an alternating way by removable joints or by welding on the top and bottom lids of the boiler. In the centre of the top lid,a spark plug is set up to ignite the fuel when started.

The advantages of Vuia's boiler are: simple construction, very easy to perform repairs (replacement of coils), quick start-up (minutes), low thermal inertia, high efficiency (95\%), very high productivity $(30 \mathrm{~kg}$ steam $\left./\left(\mathrm{m}^{2} \mathrm{~h}\right)\right)$, reduced size. Its disadvantages are: relatively low rate, it requires a good automation and good quality fuel.

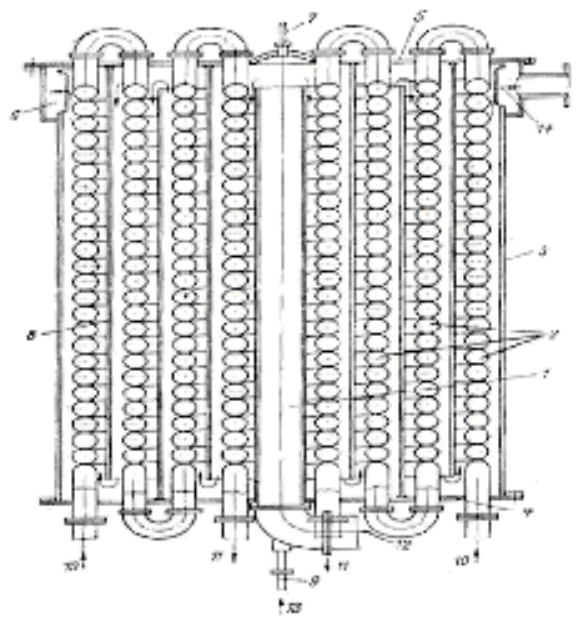

Figure 3. Vuia's four coil boiler. Functional outline: 1 furnace tube; 2 - coil; 3 - jacket; 4 - bottom lid; 5 - top lid; 6 -flue gases collector; 7 - spark plug; 8 - obstacle; 9 - injector; 10 - admission feed water; 11 - steam exit; 12
- air exit; 12 - fuel entry; 14 - gases exit [1], [4]

The boiler is generally used to produce saturated steam of 1.2-100 bars, and sometimes to produce hot water to heat urban centers or for naval needs.

Considering that the amount of water found at a certain moment in time in a coil is very small (about 300 g), the boiler is actually free of thermal inertia, so it can be put into operation in very rapidly (2-4 minutes). Furthermore, there is no danger for a coil to break, because the small amount of vapors, formed suddenly due to pressure drop, does not have the destructive effect met for example in the case of boilers with high water content.

Table 1. Dimensions of Vuia's steam generators

\begin{tabular}{|c|c|c|c|c|c|c|}
\hline $\begin{array}{c}\text { Typ } \\
\mathrm{e}\end{array}$ & $\begin{array}{c}\text { Body } \\
\text { diamete } \\
\mathrm{r}[\mathrm{mm}]\end{array}$ & $\begin{array}{c}\text { Heigh } \\
\mathrm{t} \\
{[\mathrm{mm}]}\end{array}$ & $\begin{array}{c}\text { Volum } \\
\mathrm{e} \\
{\left[\mathrm{m}^{3}\right]}\end{array}$ & $\begin{array}{c}\text { Furnace } \\
\text { tube } \\
\text { (height } \mathrm{x} \\
\text { diameter } \\
\text { ) } \\
{[\mathrm{mm}]}\end{array}$ & $\begin{array}{c}\text { Stea } \\
\mathrm{m} \\
\text { flow } \\
{[\mathrm{kg} / \mathrm{h}} \\
]\end{array}$ & $\begin{array}{c}\text { No. } \\
\text { of } \\
\text { coil } \\
\mathrm{s}\end{array}$ \\
\hline A & 275 & 550 & 0.030 & $50 \times 500$ & 210 & 2 \\
\hline B & 340 & 700 & 0.063 & $65 \times 650$ & 420 & 4 \\
\hline C & 420 & 900 & 0.125 & $80 \times 800$ & 840 & 8 \\
\hline D & 480 & 1115 & 0.200 & $\begin{array}{c}100 \times \\
1000\end{array}$ & 1680 & 16 \\
\hline E & 560 & 1365 & 0.360 & $\begin{array}{c}125 \times \\
1250\end{array}$ & 3360 & 32 \\
\hline
\end{tabular}

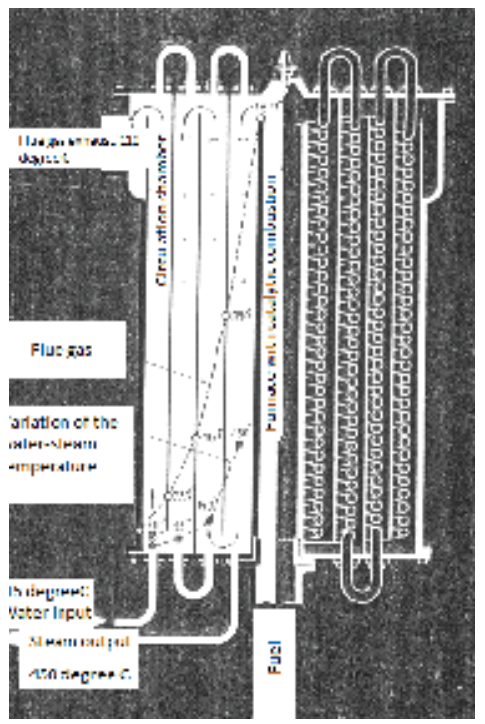

Figure 4. Section through Vuia's steam generator [1], [4]

Forced circulation boilers can operate only at pressures higher than $100 \mathrm{bar}$, in which the circulation of water as vapor takes place without variation too much the specific volume. As a result of high operating pressures, the thickness of the pipes' metallic walls is increased, but 
this increase is insignificant when the pipe diameter is small. This is the reason why Vuia chose the diameter of the coils to be only of $10 \mathrm{~mm}$, achieving a boiler weight approximately 10 times lower than for conventional boilers (Figure 4).

The validity of Traian Vuia's innovative ideas applied in the construction of steam generators was verified and confirmed by the experimental research undertaken by $\mathrm{PhD}$. Eng. G. Brolain the Laboratoire des hautes températures de Paris of the Faculty of Sciences, University of Sorbonne, which was led by professor Gustave Ribaud, member of the French Academy of Sciences. The measurements done showed that the combustion was going perfectly, with very low air excess, the obtained heat was transferred almost entirely to water and steam. The flue gases were going out of the boiler at temperatures $\mathrm{t}_{\mathrm{gc}}<60^{\circ} \mathrm{C}$, if the supply water temperature was oft $\mathrm{w}_{1}=20^{\circ} \mathrm{C}$. Under these conditions, the gross thermal efficiency of the boiler wast $\mathrm{b}_{\mathrm{b}}>95 \%$, value not found in the case of other boilers.

In some of his research, Vuia was helped by Gavrilă Brola from Banat, with whom he began collaboratingin 1934.G. Brola, together with professor G. Ribaud, continued the research started by Vuia, and, in 1952,they made a forced circulation generator, based on Vuia's principle. The generator, exhibited at the International Exhibition on Combustion in Paris, 1957, was manufactured in series in France, Belgium, England and Germany.

Traian Vuia, together with another collaborator, Emmanuel Yvonneau, patented several types of steam generators. The first patent was issued on January 21, 1928, by the French Ministry of Commerce and Industry (no. 661254), the second patent on December 22, 1928 (no. 680567) and the third on November 12, 1932 (no. 740226).

After Traian Vuia donated to the Romanian state the right to use his patents in 1950 in the Vulcan plant in Bucharest and starting with 1953 in the Energy Institute of the Academy, extensive research was carried out to determine the conditions of operation, reliability and endurance. Due to the difficulties encountered regarding both automation and the lack of consumers of a low flow of superheated steam at extremely high pressures, the principle of forced circulation was abandoned and boilers with multiple forced circulation were made instead. They had a circulation of 1 or $3 \mathrm{t} / \mathrm{h}$ saturated steam at $\mathrm{p}=17 \mathrm{bar}$ and were used in the food industry, the light one and not only. Hot water boilers of $2325 \mathrm{~kW}(2 \mathrm{Gcal} / \mathrm{h})$ were also realized which were used to equip numerous district heating micro plants (Figure 5).

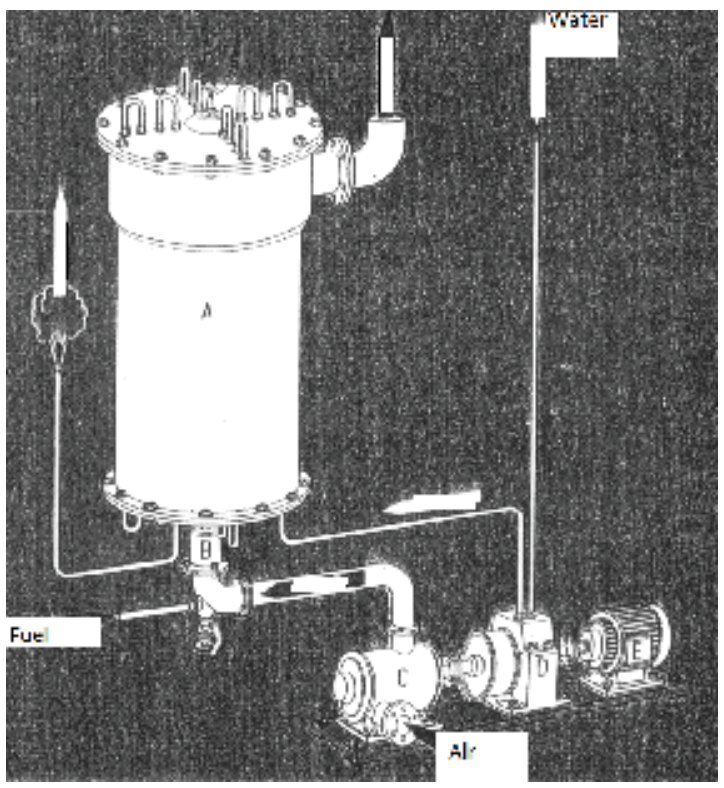

Figure 5. Vuia's boiler plant: A - steam generator, B carburetor, $\mathrm{C}$ - blower, D - circulation pump, E - electric engine. [1], [3]

\section{Conclusion: Vuia worked for the glory of humanity}

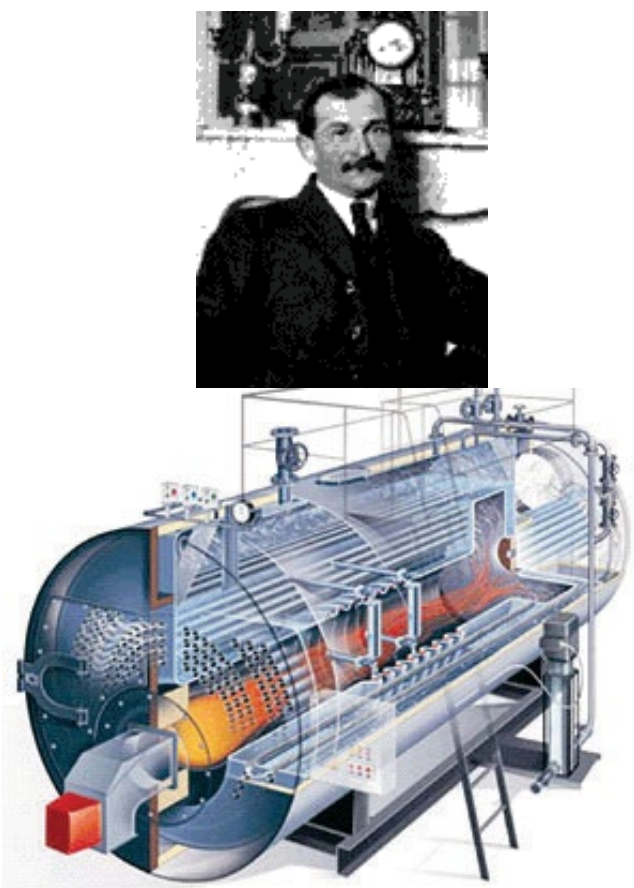

Figure 6. Vuia with the model of his invented plant, 
"What does it matter who did this thing, it is important that it exists. " Quote from Vuia [2], [3], [5]

Today, looking retrospectively, Vuia's steam generator seems a remarkable creation in the field, which opened new roads in techniques related to combustion, heat transfer and steam production. His humble personality remains in our memory (Figure 7).

The FLIGHT magazine, in the issue from March 30, London, 1956, on page 366 presented: "Vuia has been described by those who knew him as a very modest man. Indeed, he never made any other claims for his own efforts that they had contributed to the firm establishment in 1906 - 1907 of powered flight as a practical proposition. His inventiveness has been shown, and another legacy is the design of a steam generator. He was a very worthy pioneer, as much for his vision, as for his part in the earliest development of the airplane" [2].

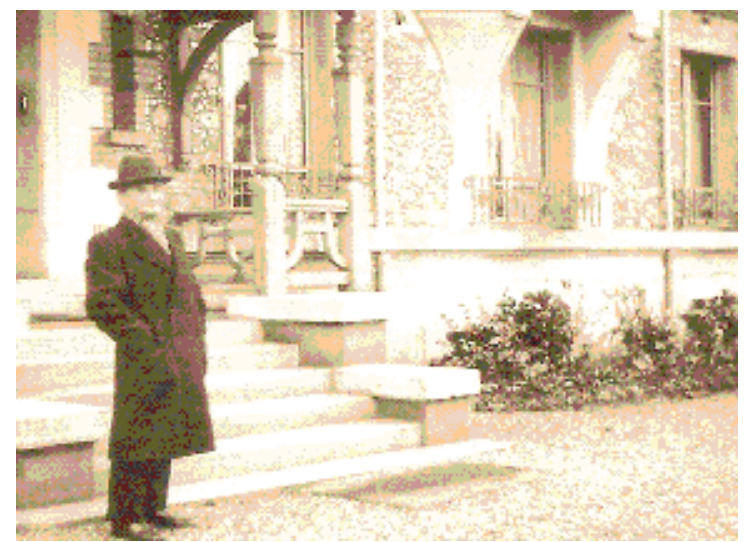

Figure 7. Vuia in front of his home, by 1939 , Garches: "I do not work for my personal glory, but for the glory of human genius". Traian Vuia - own translation, [6], [7]

"How lucky would mankind be, if there were many nations to have given to it - compared to the number of inhabitants - as much as the Romanian nation gave to it in the last 120 years." Henri Coandă

"Your value lies in what you are and not in what you have" - (Thomas Edison).
May his memory be eternal (Figure 8)!

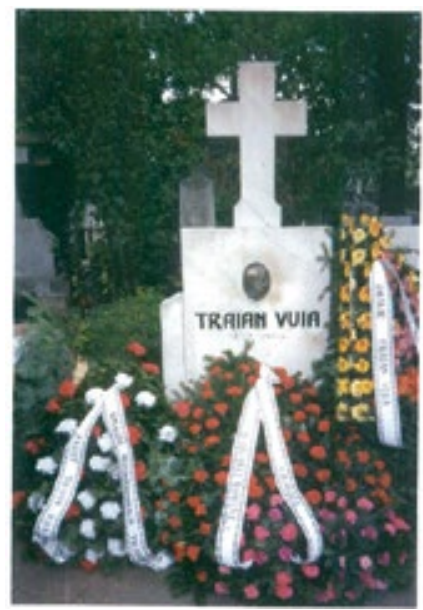

Figure 8. The grave og Traian Vuia in Bellu Cemetery, Bucharest

\section{References}

[1] M.-Ctin, Dianu, Aparate termice: cazane, Bucureşti, Editura Ministerului Administraţiei şi Internelor, 2009

[2] *** Dictionar de personalitati, www.euroavocatura.ro/dictionar/319652/Traian Vui a, accessed March 2016

[3] *** Documentary films, "Conceived in Romania (Seria de filme documentare intitulată „Gândit în România")

[4] A. Metianu, Traian Vuia Steam generator with catalytic combustion (Generatorul de abur Traian Vuia cu ardere catalitica), Editura Tehnica, 1957

[5] J. Simmons, "100 cei mai mari savanţi ai lumii", Editura Lider, 1996

[6] D. Antoniu, I. Buiu, D. Haditca, R. Homescu, G. Cicos, Traian Vuia, Viaţa şi opera (monografie bilingvă, română şi engleză), Editura Anima Bucuresti, 2013

[7] N. Iorga, Oameni care au fost, editura pt literatura, 1967 